\title{
Employment opportunities in home science education
}

\author{
REENA ROY, SHOJI LAL BAIRWA AND SUDHA BABEL
}

Received: 07.04.2015; Accepted: 26.05.2015

See end of the paper for authors' affiliations REENA ROY

Department of Textile and Apparel Designing, College of Home Science, Maharana Pratap University of Agriculture and Technology, UDAIPUR (RAJASTHAN) INDIA
ABSTRACT : Home science is a unique discipline with a blend of science and art which gives a variety of skills to the youths such as cooking, catering, processing, stitching, decoration, boutique, fashion designing, day care and health care. It also provides social and cultural values with the communication and human research development. The present study mainly focused on an overview, emerging employment opportunities and major institution of home science education in the country. In India, home science education is in its emerging stage of development, so home science graduates and post graduates have ample employment opportunities not in private sector but also in co-operative, government and semi government sector along with entrepreneurship opportunities. Home science professionals have a lot of employment opportunities in private sector (cooking, fashion designer, housekeeping, dietitians), NGOs (social welfare officer, food analysts, research officer, fashion designer) government sector (scientists, professors, research assistant) and self-employment sector (boutique, cloths designing, grooming centre, hobby centre, child care, catering and health care). Thus, home science is an emerging academic discipline which has ample opportunities of employment and entrepreneurship development in academic as well as in corporate sector.

KEY WORDS: Home science, Employment opportunities, Self-employment, Entrepreneurship development

- HOW TO CITE THIS PAPER : Roy, Reena, Bairwa, Shoji Lal and Babel, Sudha (2015). Employment opportunities in home science education. Asian J. Home Sci., 10 (1) : 260-264. 